\title{
Implementing Open Innovation: The Case of Natura, IBM and Siemens
}

\author{
Cely Ades', Aline Figlioli², Roberto Sbragia ${ }^{3}$, Geciane Porto $^{4}$, \\ Guilherme Ary Plonski ${ }^{5}$, Kleber Celadon ${ }^{6}$
}

\begin{abstract}
This paper analyses three case firms whose innovation management processes have been consolidated. The companies Natura, IBM (Brazilian Subsidiary) and Siemens (ChemTech/Brazil) were studied with the purpose of analysing the implementation of Ol, particularly in terms of: (a) its alignment with existing corporate strategy; (b) its requirements such as culture, skill and motivation; (c) the strategy and the implementation process; (d) the results achieved (e) the present barriers and enablers. The research is qualitative in nature and employs a descriptive approach. The main results of this study, obtained using a method called 'Collective Subject Speech', show that the implementation of OI, both structured and non-structured, is mainly challenged by cultural issues. It has been observed that the implementation of OI process is at its embryonic stage in all case firms and that this occurs along with investments in closed innovation, meaning that $\mathrm{Ol}$ results cannot be explored at this stage of the implementation, as there is a long way to consolidate these practices in the case firms studied.
\end{abstract}

Keywords: innovation processes; open innovation; implementation of open innovation; innovation management.

'FEA - USP / CCSA - Universidade Presbiteriana Mackenzie - Brazil. E-mail: cely@usp.br

FEA - USP - Brazil. E-mail: ${ }^{2}$ alinefig@ymail.com, ${ }^{3}$ rsbragia@usp.br, ${ }^{5}$ plonski2@usp.br

${ }^{4}$ FEARP - USP - Brazil. E-mail: geciane@usp.br

${ }^{6}$ CENTRIM - University of Brighton - Great Britain. E-mail: kleberuk@hotmail.com

ISSN: 07 I8-2724. (http://www.jotmi.org)

Journal of Technology Management \& Innovation (C) Universidad Alberto Hurtado, Facultad de Economía y Negocios. 


\section{Introduction}

The catalysing process of innovation that relies on collaboration from external organizations is a subject that has been widely explored in the literature. Coinage of the term Open Innovation (OI) Chesbrough (2003), sparked new interest in the subject, which refers not only to the internalization of knowledge, ideas and technology, but also for externalizing technologies that would not be used otherwise.

One of the phenomena that shed light onto the importance of Ol relates to the strong competition that large multinational companies face nowadays, which are generated by new entrants with fewer resources and more flexibility, placing new ideas on the market by differentiated processes, and allowing OI developments to occur more naturally. Companies that are born with the culture of Ol, whose employees are committed to the principles involved in this approach and whose internal procedures enhance the achievement of results through $\mathrm{Ol}$, will not find it difficult to act according to this new methodology. But, what happens in large companies?

In spite of much discussion around the concept of $\mathrm{OI}$ - on the processes by which it is developed and their differences in relation to models of innovation - focused on new product development, and processes that occur only within the boundaries of the company, and the benefits of adopting such an approach, little has been researched to understand how a large innovative firm undertakes $\mathrm{Ol}$ - whose internal processes of innovation have already been consolidated.

In this context, this study aims to analyse how the implementation of Ol occurred in three large companies located in Brazil: Natura, IBM and Siemens. More specifically, we have tried to identify what type corporate strategy was used; the strategy and the implementation process (implementation team and its characteristics); the $\mathrm{Ol}$ process conditioning factors such as culture, skills and motivation; existing barriers and enablers; and the results achieved. The following part shows the theoretical foundations that support the research, the methodology adopted, the results obtained, and finally, the concluding considerations of the work.

This article is divided into five sections. The first is this introduction; the second discusses theoretical precepts that support the analysis; the third related to the methodology employed; the fourth focuses on the implementation of $\mathrm{Ol}$ in the firms studied; and the fifth is dedicated to the conclusions.

\section{Theoretical Foundations}

\section{Open Innovation as part of corporate strategy}

R\&D activities that are related to products and processes and are carried out only within the walls of the company, in more traditional industrial sectors, are barriers for new entrants and contribute to keep an advantage against competitors. A more open approach allows companies to obtain advantage from ideas that would not be generated internally, and others that fit perfectly the needs of the company, but were developed outside the company. This model, whose term Open Innovation was coined by Chesbrough (2003), claims that "the company commercializes both its internal ideas and external ones from other companies, and search for ways to put their ideas on the market through the development of different routes that are not part of its usual business" (CHESBROUGH, 2003, p. 37).

Figure I shows the open innovation model and its three stages: research, development and commercialization. It has been observed that the innovation funnel, from the generation of ideas to the commercialization of products/technologies in the market, is represented by dashed lines, indicating that boundaries are permeable.

Figure I shows the processes (i) Outside-in (ideas and technology, license-in, acquisition of products, co-branding), relating to the internalization of knowledge and related resources; and (ii) Inside-out (license-out, offering technology to the market, spin outs), related to the transfer of knowledge and R\&D results for external commercialization. When both processes are carried out by the company, involving additional resource sharing among partners, the process is then called Coupled process (GASSMANN; Enkel, 2006, In Rohrbeck; Hölzle; Gemünden, 2009).

The adoption of the open innovation model does not mean that internal R\&D activities performed internally will cease, but that they will take a new role and will require new capabilities, such as the identification, understanding and access to external knowledge, the integration of both and the generation of extra revenues resulting from this integration, as shown in Figure 2.

It has been observed nowadays that companies invest heavily in both closed and open model-related activities, because the radical adoption of only one of the two models could lead to negative impacts on the innovation strategy adopted. The loss of control over key competences can result from the adoption of a fully open approach; in contrast, the increasingly shorter innovation cycles and product launching in the market cannot be achieved by the adoption of closed innovation model. Therefore, it is necessary to establish a

ISSN: 07 I8-2724. (http://www.jotmi.org)

Journal of Technology Management \& Innovation (c) Universidad Alberto Hurtado, Facultad de Economía y Negocios. 


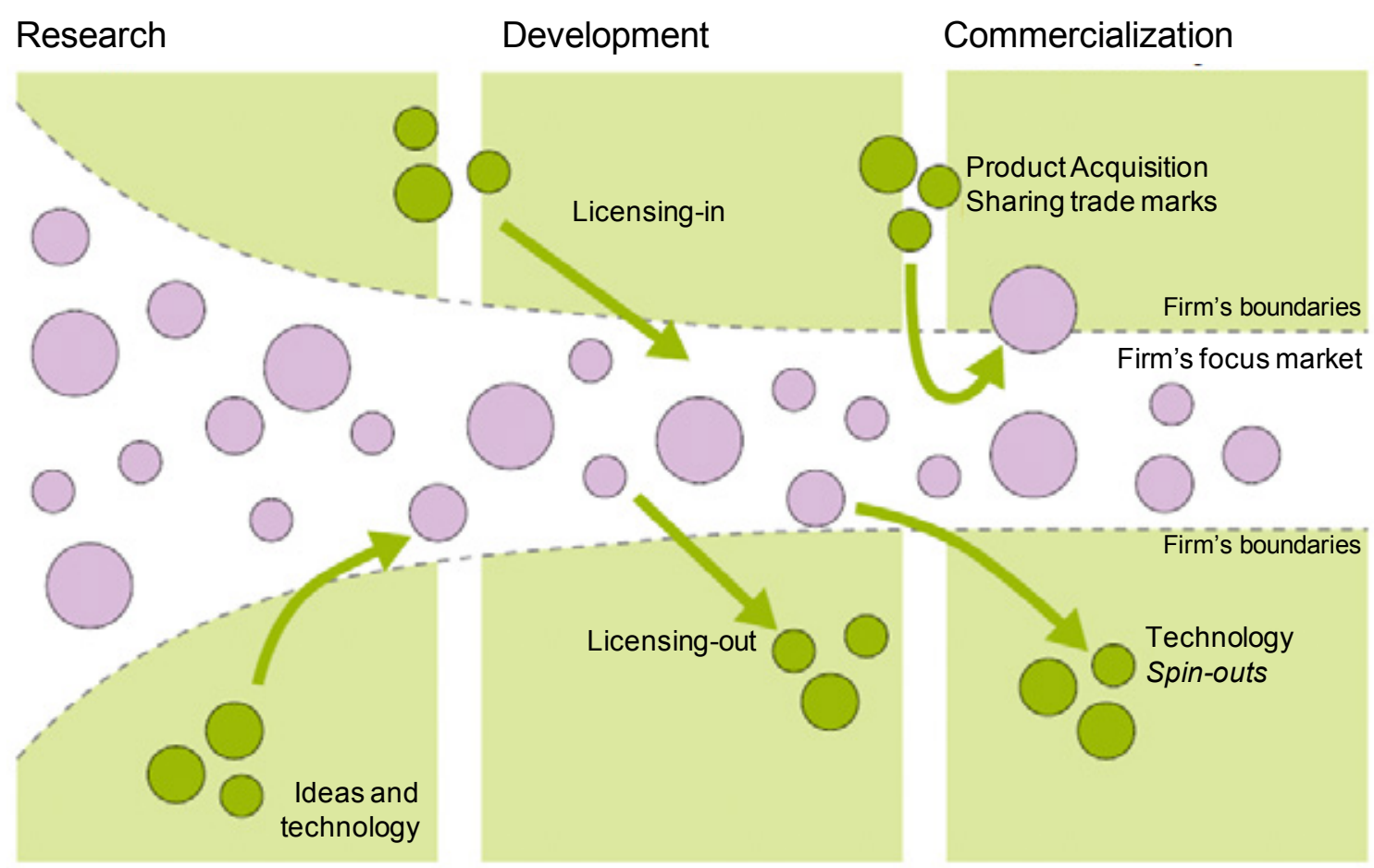

Figure I - Open innovation model. Source: Mortara (2009, p. 12)

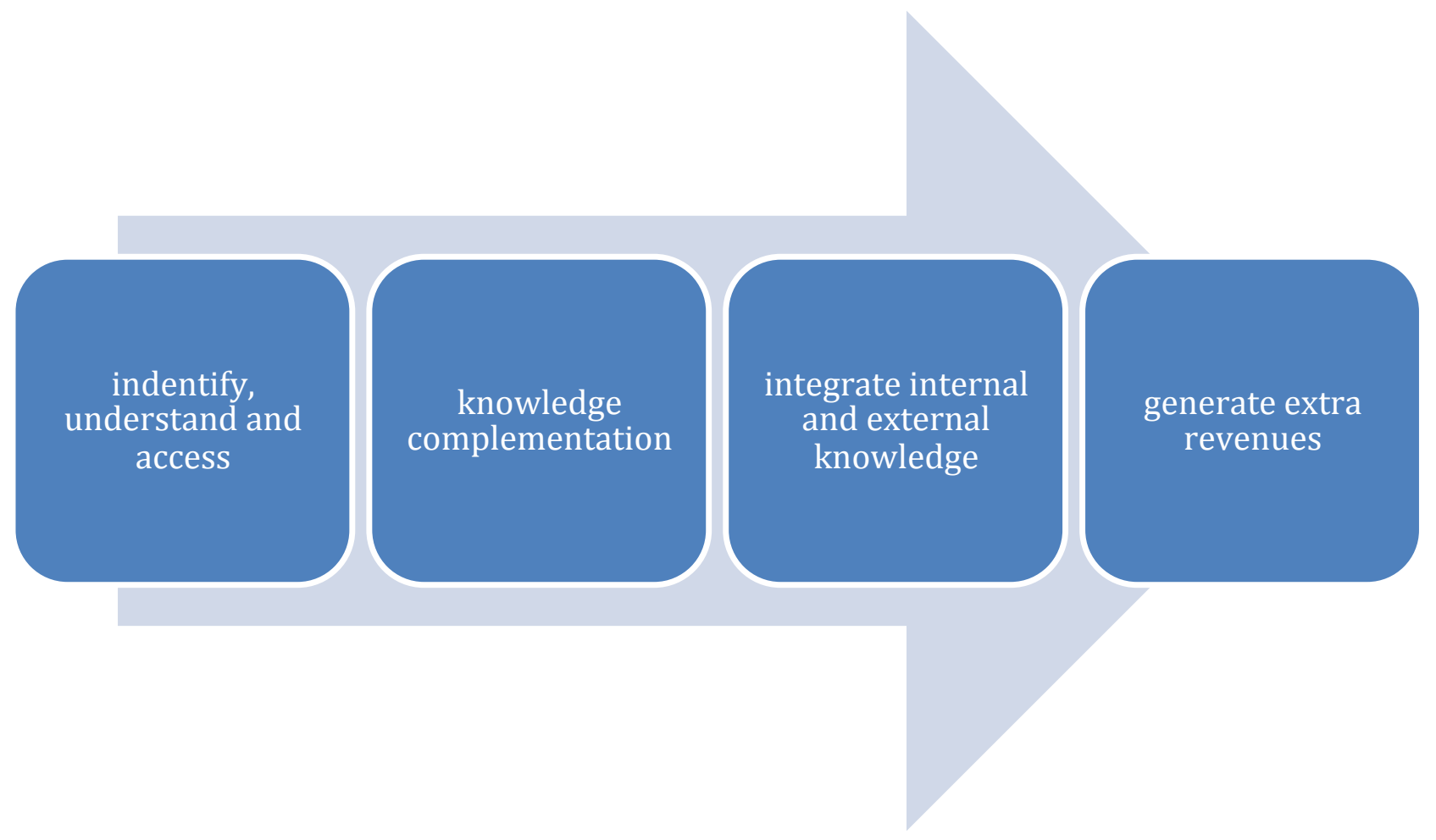

Figure 2 -Role of R\&D - Ol model (internal or external). Source: based on Knudsen (2007) 
degree of adoption of the open approach, so that the company can develop its products and services more quickly, but can also stimulate the construction of key competences and the protection of intellectual property (ENKEL; Gassmann; Chesbrough, 2009).

\section{Implementation of OI}

\section{Strategy and implementation process}

Two dimensions should be considered when it comes to the study of the strategy (or the absence of it) of implementation of open innovation by large sized companies: (a) implementation that can be guided by senior management in a top down way, or happened in a more natural way, a bottom up approach; and (b) implementation Ol that can be done in a more centralized way, by an implementation team, or in a decentralized way, by departments and other company's functions (MORTARA et al, 2009). According to Mortara et al (2009), companies that hold a mature approach in terms of OI have been through a process that was guided by higher administration, and a centralised team carried out relating activities.

Another key aspect involved in the implementation of the $\mathrm{Ol}$ is the way in which the responsibility of this process is assigned to organizational units in the company that can be: disseminated by departments and functions or centralized on a group, department or function. Considering the complexity of large companies and a more or less collaborative nature of the activities carried out in the various departments, the process of a centralized structure seems to be the most appropriate mechanism in order to integrate the vision of Ol within the firm (MORTARA et al, 2009).

The Ol team should be formed by individuals whose expertise are different, but holding a sound knowledge about the business of the company, and also about the market in which they operate (MORTARA et al, 2009). It can be noticed that the team is largely responsible for the articulation and promotion of Ol by means of involvement, training and support to related functions, and by the alignment between strategy and the vision of $\mathrm{Ol}$ adopted.

\section{Requirements}

The implementation of $\mathrm{Ol}$ in consolidated companies requires the development of actions that fulfil all requirements for open innovation, namely: the company culture, the skills of people involved in activities related to $\mathrm{Ol}$ and their motivation to achieve results through OI (MORTARA et al, 2009). Table I presents the desirable characteristics for each of the requirements as well as examples of mechanisms that can help in the achievement of these characteristics.

\begin{tabular}{|l|l|l|}
\hline Requirements for OI & Desirable for OI & Example of mechanisms for the development of a desirable environment \\
\hline Culture & $\begin{array}{l}\text { Collaborative and } \\
\text { open culture (can } \\
\text { vary between de- } \\
\text { partments/functions } \\
\text { according to the } \\
\text { activity developed) }\end{array}$ & $\begin{array}{l}\text { - Capabilities for the development of collaborative activities and partnerships; } \\
\text { - Events for the intensification of networking; } \\
\text { development programs; } \\
\text {-Value ideas/technologies obtained externally, in an attempt to minimize the } \\
\text { "Not Invented Here" syndrome; } \\
\text { - Support by top management. }\end{array}$ \\
\hline Capabilities & $\begin{array}{l}\text { Set of internal abil- } \\
\text { ities that allow the } \\
\text { access and assess- } \\
\text { ment of capabilities } \\
\text { as well as external } \\
\text { opportunities. }\end{array}$ & $\begin{array}{l}\text { - Training and development programs that give support over technical abil- } \\
\text { ities and introspective (internal business analysis), "extrospective" abilities } \\
\text { - Selection of people that possess technical and introspective abilities, "ex- } \\
\text { trospective" abilities as well as interactive ones; } \\
\text { - Promotion of interaction among people with different skills; } \\
\text { - Job rotation. }\end{array}$ \\
\hline Motivation & $\begin{array}{l}\text { Low resistance to } \\
\text { the introduction } \\
\text { of Ol } \\
\text { Rewarding that } \\
\text { support the Ol } \\
\text { approach }\end{array}$ & $\begin{array}{l}\text { - Involvement of people in the decision making process; } \\
\text { - Improvement of internal and external communication processes; } \\
\text { apewarding systems and career plans based on metrics related to results } \\
\text { generated by Ol. }\end{array}$ \\
\hline
\end{tabular}

Table I - OI Requirements. Source: based on Mortara (2009), Viskari et al (2007), and Chesbrough (2003).

ISSN: 07 I8-2724. (http://www.jotmi.org)

Journal of Technology Management \& Innovation (c) Universidad Alberto Hurtado, Facultad de Economía y Negocios. 


\section{Barriers and enablers for the implementation of open innovation}

In a research carried out by Mortara et al (2009) in 16 large companies, it has been identified that the two main facilitators for the implementation of $\mathrm{Ol}$ are related to the company culture (support of higher management and the creation of OI culture); the undertaking of adequate structural changes, a factor that is related to the process, appears in third place. In the same study it was identified that the main barrier also refers to internal cultural issues, which demonstrates the strength of the organizational culture in the success or failure of when implementing $\mathrm{Ol}$ in the company.

West and Gallagher (2006) present strategies to address challenges of open innovation, highlighting the maximization of returns originated by internal innovation, the role of external innovation and the motivations for external innovation, as can be seen in table 2 .

\section{Results generated by the use of open innovation}

The adoption of open innovation approach can cause an impact on the business model adopted by the firm, allowing it to capture value by using its assets, resource or the firm's key positioning, not only in its own operations, but also in the business of other companies (CHESBROUGH, 2007). In fact, new sources of revenue coming from licensing, spin-off (startup firms) and the selling of new technology that has not been used by the company and, at the same time, reduced develop- ment costs and time savings in new product development and processes are some of the impacts that can be caused by the adoption of $\mathrm{Ol}$. Figure 3 ilustrates this phenomenon.

Results linked to the bottom line of the company - related to revenues and costs - as well as results related to the mechanisms by which Ol is developed should be taken into account and measured appropriately.

In relation to metrics, various authors addressed the topic of evaluating innovation observing various aspects. Figueiredo (2009), Kenneth et al (1999), Andreassi and Sbragia (2002) support the idea of the company's ability to generate innovations, focusing this observation on resources, capabilities, structure and culture present in the organization. Others (TIDD, 2008; Drucker, 2003; Takahashi And Takahashi, 2007, Christensen, 2000 And Moore, 2008) perceive metrics after crossing the entire innovation process, that is, results are measured after the product or service are set in the market or after the process has generated results, be it an increase in quality or cost reduction.

In any case, the metrics that put emphasis on capabilities and competencies do not guarantee present or future results from innovation. Likewise, the assessment of these results does not guarantee that the company is innovative or that it can assure future results relating to innovation, because it cannot be concluded that current gains result solely from a favourable situation.

\begin{tabular}{|l|l|l|l|l|}
\hline $\begin{array}{l}\text { Strategies from } \\
\text { open sources }\end{array}$ & Challenges & $\begin{array}{l}\text { Maximizing returns from } \\
\text { internal innovation }\end{array}$ & $\begin{array}{l}\text { Role of external inno- } \\
\text { vation }\end{array}$ & $\begin{array}{l}\text { Motivation for external } \\
\text { innovation }\end{array}$ \\
\hline $\begin{array}{l}\text { R\&D organiza- } \\
\text { tion }\end{array}$ & $\begin{array}{l}\text { Coordination and } \\
\text { alignment of inter- } \\
\text { ests }\end{array}$ & $\begin{array}{l}\text { Participants contribute as } \\
\text { a team and share efforts. }\end{array}$ & $\begin{array}{l}\text { Gathering contribu- } \\
\text { tions that are available } \\
\text { for all. }\end{array}$ & $\begin{array}{l}\text { Institutions should } \\
\text { establish legitimacy and } \\
\text { continuity incessantly }\end{array}$ \\
\hline Spin-outs & $\begin{array}{l}\text { Sustainability of } \\
\text { third party interests. }\end{array}$ & $\begin{array}{l}\text { Seed non commercial } \\
\text { technologies in order to } \\
\text { reach other objectives. }\end{array}$ & $\begin{array}{l}\text { Implement internal } \\
\text { innovation based on } \\
\text { continuous innovation }\end{array}$ & $\begin{array}{l}\text { Free Access to valuable } \\
\text { Technologies. }\end{array}$ \\
\hline $\begin{array}{l}\text { Sales of comple- } \\
\text { ments }\end{array}$ & $\begin{array}{l}\text { Maintenance of } \\
\text { differences in shared } \\
\text { components and } \\
\text { capabilities }\end{array}$ & $\begin{array}{l}\text { The most valued target is } \\
\text { the solution of all parts of } \\
\text { a product. }\end{array}$ & $\begin{array}{l}\text { External components } \\
\text { are the basis for inter- } \\
\text { nal development. }\end{array}$ & $\begin{array}{l}\text { Firms coordinate contin- } \\
\text { uous supply of compo- } \\
\text { nents. }\end{array}$ \\
\hline $\begin{array}{l}\text { Donation of } \\
\text { complements }\end{array}$ & $\begin{array}{l}\text { Third party can } \\
\text { control users. }\end{array}$ & $\begin{array}{l}\text { Offer a platform that can } \\
\text { be extended to external } \\
\text { partners. }\end{array}$ & $\begin{array}{l}\text { Add up a variety of } \\
\text { novelties in acclaimed } \\
\text { products }\end{array}$ & $\begin{array}{l}\text { Acknowledge non-mone- } \\
\text { tary forms of rewarding. }\end{array}$ \\
\hline
\end{tabular}

Table 2 - Strategies to solve the challenges in open innovation. Source:Adapted from West \& Gallagher (2006)

ISSN: 07 I8-2724. (http://www.jotmi.org)

Journal of Technology Management \& Innovation (C) Universidad Alberto Hurtado, Facultad de Economía y Negocios. 
Figueiredo (2009) presents two sets of metrics: an approach based on the construction of national indicators, and measurement strategy, based on types and levels of technological capacity. This second approach involves both production activities and innovation. The author also presents various types of evaluation metrics based on technological capacity in companies that belong to emergent economies, which includes, among others, R\&D statistics, patents statistics and statistics related to expenditure on machinery and equipment; In addition, he makes comments about the importance of learning processes.

In this second group of metrics with a focus on learning, Figueiredo (2009) differentiates inter-company processes with transaction-based ties of market for goods and services - from those based on knowledge-flow, which is subdivided into: existing technology (routinely produced) and links to innovation. These processes can promote the use of technological capabilities, the development of technological capabilities (learning) and the reverse development of technological capabilities.
The author also suggests that da difference should be made between metrics for informal connections, human resources and formal links. The metrics for informal links may consider: (I) informal contacts with researchers; (2) access to specialized literature; (3) access to research of specific departments; (4) participation in seminars and conferences; (5) access to University equipment and/or research institutes; (6) participation in specific programmes (education and training); (7) other informal connections. The metrics for assessing learning processes based on human resources are: $(I)$ involvement of students in industrial projects; (2) recruitment of new graduates; (3) recruitment of experienced scientists and engineers; (4) formally organized training programs to meet the needs of human resources. In relation to the evaluation of formal links, he suggests: (I) consulting services developed by researchers or consultants; (2) analysis and testing (technical tests); (3) update database services; (4) technical answers; (5) establishment of research contracts; (6) the establishment of collaborative research; (7) other formal links.

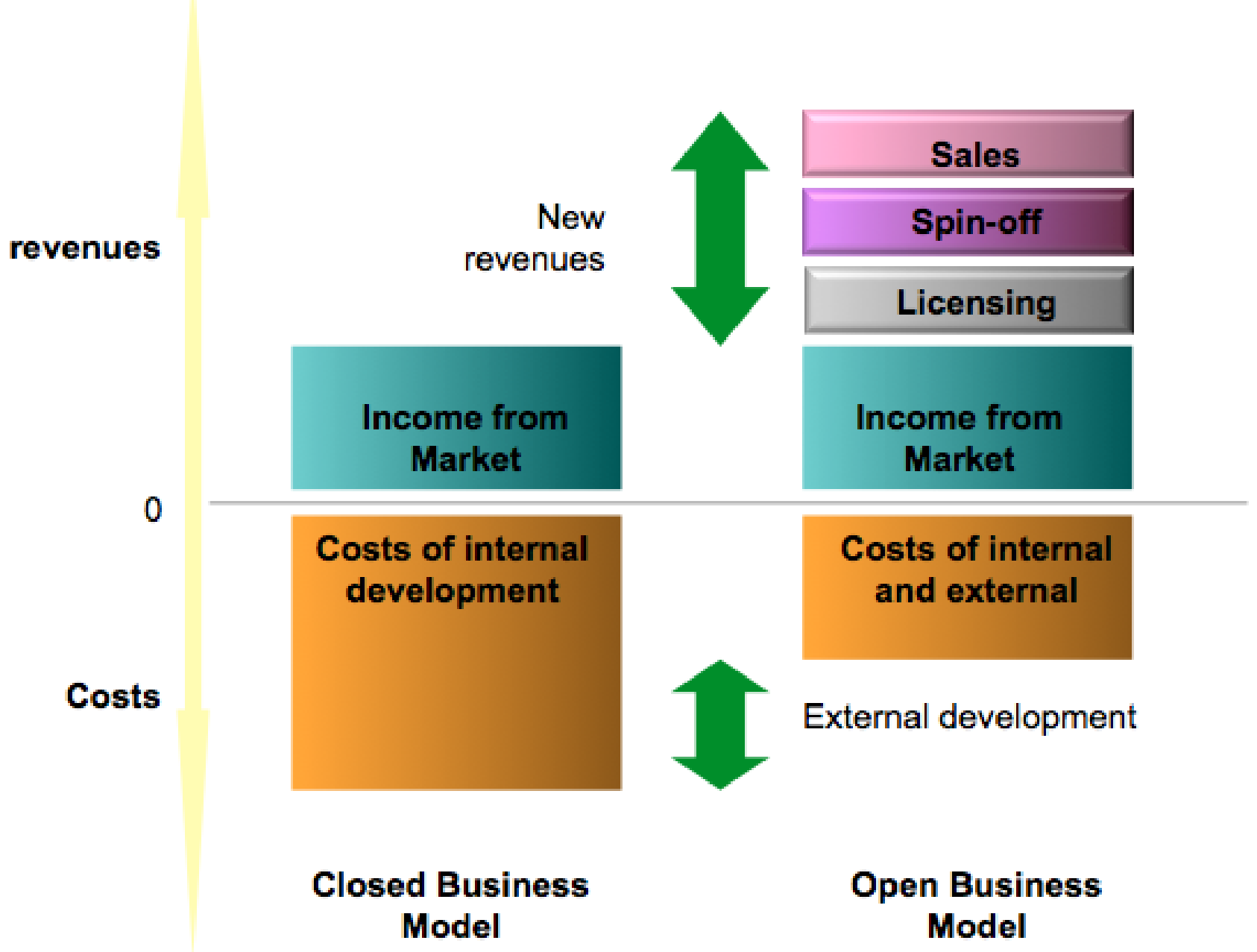

Figure 3 -Impact on revenue and costs generated by OI. Source:Adapted from Chesbrough (2007, p. 27)

ISSN: 07 I 8-2724. (http://www.jotmi.org)

Journal of Technology Management \& Innovation (c) Universidad Alberto Hurtado, Facultad de Economía y Negocios. 
Some indicators that appear to be aligned to the effective adoption of $\mathrm{Ol}$ are related to: (a) licensing of technologies; (b) attracting Venture Capital to projects in partnership; (c) generation of spin-offs using company's technologies; (d) projects developed in collaboration with science and technology institutions and other companies; (e) alliances and acquisitions aimed at OI process; (f) products/processes developed in partnership or with technology obtained externally; $(\mathrm{g})$ revenue generated through the sale of technologies developed by the company.

In conclusion, both metrics related to result and those that focus on the process of innovation - and the ability to innovate of the company - can be applied in some way or another in Ol. The metrics focusing on learning are those more easily connected to the practice of OI.

\section{Methodology}

This research employs a qualitative approach because it is the most recommended to understanding the nature of a social phenomenon. The first phase of this research is exploratory, as it is based on authors whose focus are not only on the open innovation theme, but also on its implementation process, as well as on the variables influencing this process, within this approach to innovation in large companies. The exploratory research, according to Richardson (1999, p. 326), has to "know the characteristics of a phenomenon and then to search for explanations of the causes and consequences of such phenomenon". According to Ruiz (1992, p. 50), this type of research "consists of an initial characterization of the problem, their classification and their proper definition".
Figure 4 shows the theoretical and conceptual model of this research. The study sought to verify the process of implementation of open innovation through the understanding of how input factors were treated (culture, skills and motivation), the process itself (procedures adopted for implementation), the barriers and facilitators of the process and the results of the implementation of $\mathrm{Ol}$ in the company.

The study was carried out focusing on three cases, Natura, IBM (Brazil) and Siemens/Chemtech. Some characteristics of these firms are:

\section{Natura}

Natura is a brand of Brazilian origin and it is present in seven Latin American countries and in France. It became an open market firm in 2004. In Brazil it is the market leader in the cosmetics sector, fragrances and personal care, as well as in the direct selling distribution method and its strategy is based on innovation.

\section{IBM}

IBM, a company in the information technology sector focuses on strategic innovation, aiming to implement an innovation laboratory in Brazil until 2014. The firm is the leader in the number of patents in the United States for the 14th time, and about 4,500 patents were granted in 2009. The problem is the lack of use of these patents and the difficulty in managing the knowledge generated in their labs. In this context, the company does not seek to implement open innovation, but has invested in converting inventions into in-

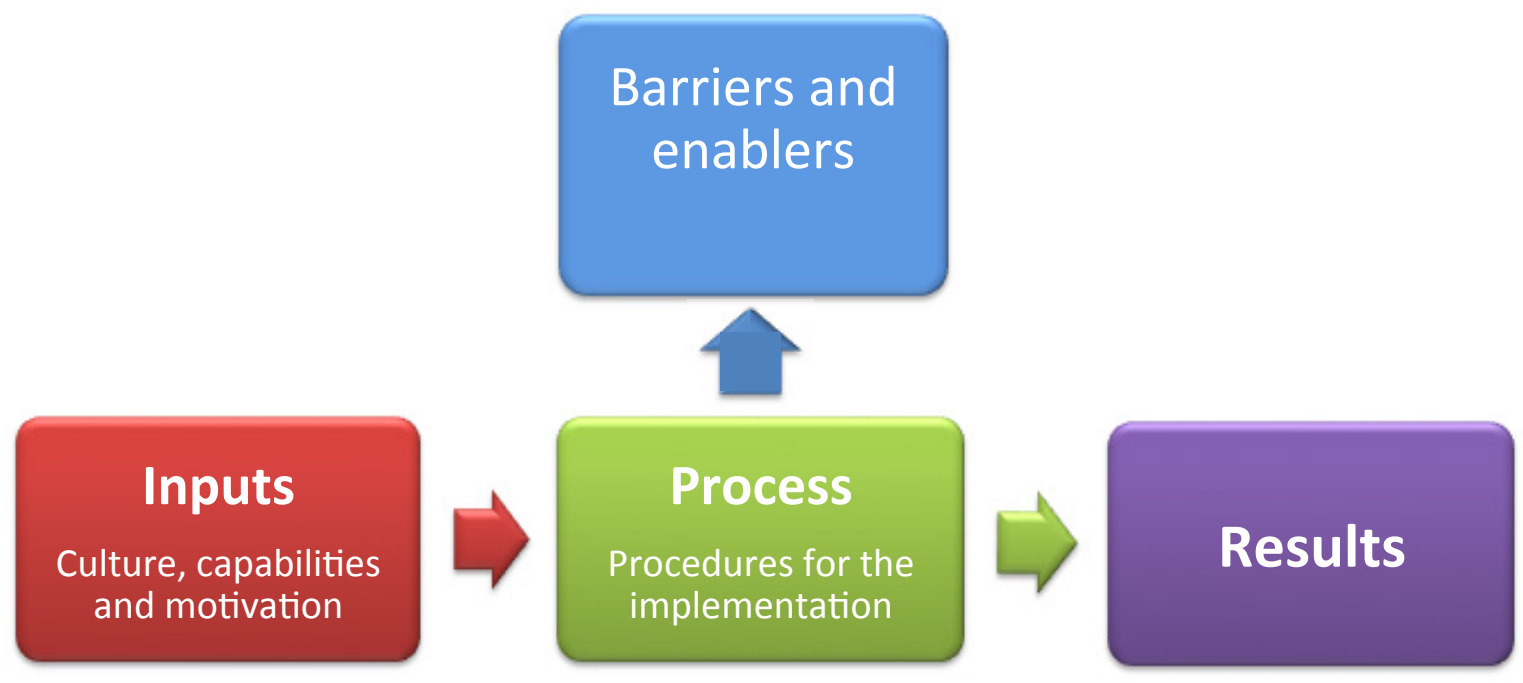

Figure 4 -Theoretical research conceptual Model

ISSN: 07 I8-2724. (http://www.jotmi.org)

Journal of Technology Management \& Innovation (c) Universidad Alberto Hurtado, Facultad de Economía y Negocios. 
novations. The firm prioritise the portfolio management of knowledge over the implementation of OI at IBM. Previous negative experience with $\mathrm{Ol}$ generated a lack of credibility in this approach, mainly because the company does not understand it as a possibility of generating financial returns, but as a factor of complexity in the existing processes.

\section{Siemens-Chemtech}

Chemtech is an engineering and software company of the Siemens group that has competence in the areas of basic engineering, automation and control in IT. Currently the company employs around I,240 employees and is headquartered in Rio de Janeiro, Brazil, holding a young profile as $75 \%$ of its employees are in the age group of 30 years old.

Descriptive studies, according to Sampieri et al (2006, p. 102) "aim to measure or collect information independently or composedly about the concepts or variables that they refer to". We have opted for the use of multiple case studies, because, according to Eisenhardt and Graebner (2007, p. 27), it makes the findings "best supported, more accurate and more generalizable". According to the authors, studies involving multiple cases allow you to:

a) make comparisons between cases, allowing you to verify if the results are related to only one case or appear consistently in several cases;

b) create more robust theory, since this is derived from propositions that are supported by further study and evidences in several cases;

c) extend the exploration of research questions;

d) increase the quality of the theory developed by adding few cases of research, since the number of cases used is usually small.

The choice of the cases in this study took into account suggestions from experts in innovation management of large companies that are also users of the open innovation model, as well as the easiness of access to the data in these firms. The answers were obtained by means of semi-structured interviews and visitation (observation) to innovation rep- resentatives in each company and were analysed by means of the method of the collective subject discourse (DSC). This technique uses central ideas (description), key words (content or substance) and attaching (theory in which a specific situation is framed) to analyse the discourse (LEFÈVRE; Lefèvre, 2005), obtained from interviews.

\section{The implementation of $\mathrm{Ol}$ in the firms studied}

The implementation of $\mathrm{Ol}$ occurs differently in the three companies studied as shown in the tables below. The keyexpressions obtained using the DSC method were inserted in subsequent analyses of the scenario, anchored on the objectives of the study.

It has been observed that the concept of $\mathrm{OI}$ was employed in the case firms, be it clearly or not: Natura adopts OI strategies since 2006, Chemtech decided to implement the formal process of $\mathrm{OI}$ in 2010 and IBM does not recognize the $\mathrm{Ol}$ as an innovation strategy as concept does not match the company's culture and also due to negative experiences related to openness. In spite of that, this study will consider that IBM practices OI because several actions of this strategy were identified in its activities in the form of partnerships, external knowledge search, patent licensing, even it has not been structure for this purpose.

Strategically, what has motivated companies to implement $\mathrm{Ol}$ is the prospect of obtaining resources from government and the market credibility gained by them making alliances with universities, enhancing the company's image, in addition to the contributions of the $\mathrm{Ol}$ process for the organization. In this sense, the three companies develop research internally and seek external expertise, characterized by the outside-in, but in different ways. IBM prioritizes the acquisitions of companies at the expense of partnerships and license in of technologies, not mentioning income from external financial resources as something important to the practice of $\mathrm{Ol}$. Only IBM practices the inside-out modality of OI, a practice considered as a marketing strategy by the organization, which has not generated financial results. Although there

\begin{tabular}{|c|c|c|c|}
\hline & Natura & IBM & Siemens \\
\hline $\begin{array}{l}\text { Innovation } \\
\text { Strategy }\end{array}$ & $\begin{array}{l}\text {-Strategic alignment with OI } \\
\text {-Began OI in } 2006 \\
\text { - Perceive an increase in credibil- } \\
\text { ity when establish partnerships } \\
\text { with universities } \\
\text { - Ol strategy is motivated by the } \\
\text { use of governmental resources }\end{array}$ & $\begin{array}{l}\text { - Strategy priority is in the ac- } \\
\text { quisitions not in partnerships } \\
\text { - Adoption of strategy of not } \\
\text { sharing patents. } \\
\text { - Licensing-in and firm aquisi- } \\
\text { tions }\end{array}$ & $\begin{array}{l}\text { - Strategically aligned with } \\
\text { OI } \\
\text {-Began Ol implementation } \\
\text { in } 2010\end{array}$ \\
\hline
\end{tabular}

Table 3- Differences on innovation strategies in the case firms

ISSN: 07 I8-2724. (http://www.jotmi.org)

Journal of Technology Management \& Innovation (c) Universidad Alberto Hurtado, Facultad de Economía y Negocios. 
is a complementarity between closed and open innovation models in organizations, the coupled process has not been identified in any of them.

Natura has created a centralized unit within its vice-presidency for innovation, management of innovation and partnerships (GIP) that is formed by II people, which is linked to the other directors in the firm. Is divided into three functions: intellectual protection, projects/processes, the relationship between company/University/Research Institute, funding and licensing. It uses the process of forwarding partnership actions to the Network Management Committee, then proposing a contractual form for hiring the scope of each project - technical, scientific or basic research; or focusing on services - in which risks are analysed, as well as appropriate funding source, timing for signing agreements/ contracts, and prospecting other partners in case the initially planned do not meet the required schedule.

A new R\&D directorship is being structured at Siemens in order to manage competences and knowledge already disseminated in the company. The Chemtech Research, a Chemtech sector responsible for R,D\&l, is organized as follows: (I) Coordination of Research \& Development projects: responsible for the management of R\&D portfolio; technological prospecting; implementation of research projects and development of new products and solutions; and, management of partnerships with national and international R\&D centres (to encourage open innovation); (2) Intellectual Property Management: responsible for protecting solutions that have potential for patenting or registrations, or promote the dissemination of knowledge through events, publications and journal articles; (3) management of tax incentives: responsible for using Government incentives and to follow government initiatives and proposals that support innovation.
Regarding the process of implementation of OI, the approach was unique: it was identified the bottom up approach at Natura, as it emerged from the initiative of a group of relationships with universities, and top down at Siemens, originated by the request of senior management. It can be said that all companies in the implementation of $\mathrm{Ol}$ are centralized (Figure 5), and at IBM, - represented by dotted line - which does not explicitly adopts OI, there is a department dedicated to the licensing of technologies.

The stages of implementation of the $\mathrm{Ol}$ at Natura and Siemens are at different stages, being the first, more mature. At Natura Ol is a vision that has been explicitly integrated in their managerial activities, evidenced by its structure, motivators and concerns with changing the firm's culture.

Before the adoption of the strategy of Ol, each department at Natura assessed the benefits of inputs made individually. Nowadays, all areas act in a crossed management way to ap-

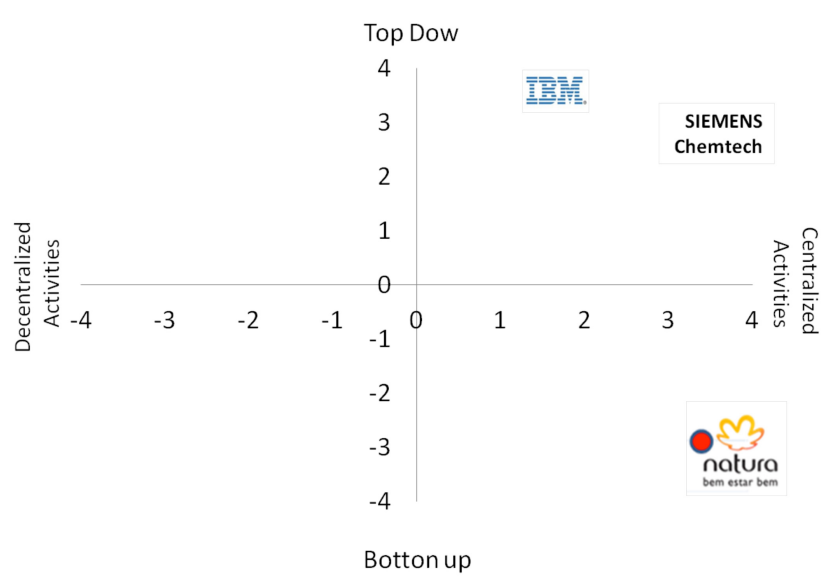

Figure 5: Implementation of the OI

\begin{tabular}{|l|l|l|l|}
\hline & Natura & IBM & Siemens/ChemTech \\
\hline $\begin{array}{l}\text { Strategy and } \\
\text { the process of } \\
\text { implementation } \\
\text { of OI }\end{array}$ & $\begin{array}{l}\text { - Promotes internal } \\
\text { research and search for } \\
\text { openness } \\
- \text { Initiative from the firm's } \\
\text { team responsible for part- } \\
\text { nerships } \\
\text {-Bottom-up }\end{array}$ & $\begin{array}{l}\text { - Promotes internal research } \\
\text { and do not search for open- } \\
\text { ness } \\
\text { - They are against the idea of } \\
\text { openness }\end{array}$ & $\begin{array}{l}\text { - Promotes internal research and search } \\
\text { for openness } \\
\text {-Iniciative from top management; } \\
\text {-Top-down }\end{array}$ \\
\hline $\begin{array}{l}\text { Team/Structure } \\
\text { of OI }\end{array}$ & $\begin{array}{l}- \text { Structured Deparment } \\
\text { for Ol } \\
\text {-Centralized structure }\end{array}$ & $\begin{array}{l}\text { - Don't plan to implement OI } \\
\text {-Innovation and Ol are not } \\
\text { structured } \\
- \text { The firm has a department } \\
\text { responsible for licensing-out }\end{array}$ & $\begin{array}{l}\text { - Began planning the implementation of } \\
\text { Ol Centralized structure } \\
\text {-Use own multidisciplinary team of } \\
\text { R\&D for OI. No changes in structure } \\
\text { for this. }\end{array}$ \\
\hline
\end{tabular}

Table 4 - Strategy and team structure in the three case firms.

ISSN: 07 I8-2724. (http://www.jotmi.org)

Journal of Technology Management \& Innovation (c) Universidad Alberto Hurtado, Facultad de Economía y Negocios. 
prove joint projects, avoiding a single analysis made only with financial focus. The program Natura Campus was developed with the aim of changing culture internally, but also in universities and Science \&Technology Institutes. On the other hand, the concept of OI at IBM is that this innovation model can only be applied at the stage previous to the patenting or, otherwise, it can be seen as a corporate charitable action.

In relation to motivating factors, not all companies in this study valued knowledge originated from external sources the same way. In the case of IBM, the internal R\&D structure and its production of knowledge has served as the basis in the process of innovation. Siemens, with its corporate university, is concerned with training and the dissemination of knowledge within the firm. A research-oriented career can be considered as a motivator at IBM and Natura.

The Ol team is formed, in all three companies, by employees with different backgrounds with a good knowledge of the business and the market, which can be characterized as a facilitating factor in the process in question. On the other hand, the culture of the country can be considered as a barrier or a facilitator of innovation and OI. In Brazil, which still a developing country, planning for innovation is less intense in comparison with developed countries. So, the need for survival can encourage the search for solutions outside the company.
Natura emphasises on the practice of informal links with universities by means of research contracts and joint research. IBM, on the other hand, uses formal connections with more intensively, involving students in industrial projects and the recruitment of scientists.

Respondents affirm that when support if given from senior management, and also when internal and external communication presents few obstacles, the implementation of $\mathrm{Ol}$ is more likely to offer results. However, even in companies that have the support of senior management, there is difficulty in the assimilation of the concept of $\mathrm{Ol}$ by its contributors and, therefore, the time for building an internal culture of $\mathrm{Ol}$ can vary, but in general takes a long time. As Ol has to be aligned with the company's strategy, internal resources and support - not only from top managers but also of the departments - are offered to support closer relationship that are a necessity for structuring it.

Apart from cultural aspects, the need for adaptation and the complexity of the projects involved, as well as contracts that generate costs and present huge challenges for management can also be considered barriers for implementation of $\mathrm{Ol}$. According to the interviewees, there are difficulties to align business project deadlines with professionals in universities and S\&TI, confirming culture as one of the main barriers to OI. One of the interviewees said that the University has no

\begin{tabular}{|c|c|c|c|}
\hline & Natura & IBM & Siemens/ChemTech \\
\hline Culture & $\begin{array}{l}\text {-Collaborative and open culture } \\
\text { among departments. } \\
\text {-Launching Natura Campus pro- } \\
\text { gramme to consolidate collabora- } \\
\text { tion with universities. } \\
\text { - Structuring research platforms that } \\
\text { allowed contracted professionals to } \\
\text { collaborate in partnership creating a } \\
\text { culture for OI. }\end{array}$ & $\begin{array}{l}\text {-Search of innovation in devel- } \\
\text { oping countries is motivated } \\
\text { by firm's needs, which favours } \\
\text { innovation. } \\
\text {-Value internally developed } \\
\text { research. }\end{array}$ & $\begin{array}{l}\text {-Chem Tech Research that is } \\
\text { only one of the innovation } \\
\text { sources at Siemens, has a } \\
\text { continuous contact with other } \\
\text { areas that are also focused on } \\
\text { innovation such as: HR direc- } \\
\text { tors; Commercial - prospects } \\
\text { technology and market; Oper- } \\
\text { ations, that makes innovation } \\
\text { available to the market. }\end{array}$ \\
\hline Motivators & $\begin{array}{l}\text {-Improvement of internal and exter- } \\
\text { nal communication } \\
\text {-Metrics related to the results gen- } \\
\text { erated by OI (still being built) }\end{array}$ & -There are no motivators & $\begin{array}{l}\text {-Improvement of communica- } \\
\text { tion between R\&D and other } \\
\text { departments. }\end{array}$ \\
\hline Capabilities & $\begin{array}{l}\text {-Scientific career in } \mathrm{Y} \text { and earnings } \\
\text { linked to the development of proj- } \\
\text { ects in partnership }\end{array}$ & $\begin{array}{l}\text { - Contracting independent } \\
\text { researchers and PhDs in partner- } \\
\text { ship with S\&TIs. }\end{array}$ & $\begin{array}{l}\text {-Corporate University is part } \\
\text { of R\&D }\end{array}$ \\
\hline
\end{tabular}

Table 5 - Culture,motivators and capabilities at the three case firms.

ISSN: 07 I8-2724. (http://www.jotmi.org) 


\begin{tabular}{|l|l|l|l|}
\hline & Natura & IBM & Siemens/ChemTech \\
\hline Barriers & $\begin{array}{l}\text {-Culture: rejected initially - "not } \\
\text { invented here syndrome". } \\
- \text { Internal researchers felt inse- } \\
\text { cure }\end{array}$ & $\begin{array}{l}\text {-Internal culture is contrary to OI. } \\
\text {-Complex Project management } \\
\text {-Need of adaptation and high risk that } \\
\text { technology does not convert into } \\
\text { innovation. } \\
\text {-Ol contract complexity and legal issues } \\
\text {-Universities are not prepared to man- } \\
\text { ager intellectual property/capital }\end{array}$ & $\begin{array}{l}\text {-Difficulty to match } \\
\text { commercial projects } \\
\text { with S\&TI timing. }\end{array}$ \\
\hline Enablers & $\begin{array}{l}\text {-Culture of internal and external } \\
\text { research as complementary. } \\
\text {-Support from top management } \\
\text {-Integration between departments } \\
\text {-Matrix structure and consolida- } \\
\text { tion of the area responsible for } \\
\text { innovation } \\
\text {-World trend to implement Ol } \\
\text { and the vision that Ol brings } \\
\text { opportunities to the firm. }\end{array}$ & $\begin{array}{l}\text {-The firm holds a unit dedicated and } \\
\text { responsible for patenting and licensing } \\
\text { technologies. } \\
\text {-Creativity favours innovation in Brazil }\end{array}$ & $\begin{array}{l}\text { - Strategic alignment } \\
\text { of the organization } \\
\text { with innovation } \\
\text { strategies and } \\
\text { support from top } \\
\text { management. }\end{array}$ \\
\hline
\end{tabular}

Table 6 - Barriers and enablers of $\mathrm{Ol}$ at the three case firms.

\begin{tabular}{|c|c|c|c|}
\hline & Natura & IBM & Siemens/ChemTech \\
\hline $\begin{array}{l}\text { Metrics for } \\
\text { Ol }\end{array}$ & $\begin{array}{l}\text { - Specific metrics for OI } \\
\text { are still being created; al- } \\
\text { ready have internal metrics } \\
\text { for participation in projects } \\
\text { made in partnership. } \\
\text { - Agreements with univer- } \\
\text { sities focusing on basic and } \\
\text { applied research }\end{array}$ & $\begin{array}{l}\text { - No metrics for evaluation of OI re- } \\
\text { sults. Patents are used as metrics for } \\
\text { innovation, but they affirm that they } \\
\text { are not the best measurement. Finan- } \\
\text { cial parameters are the main ones, } \\
\text { even though some types of innovation } \\
\text { cannot be financially measured. }\end{array}$ & $\begin{array}{l}\text { - No specific metrics for OI. } \\
\text {-Criteria adopted to present } \\
\text { are strategic such as con- } \\
\text { quering new customers for } \\
\text { example. }\end{array}$ \\
\hline Results & $\begin{array}{l}\text { - Don't practice license } \\
\text { out yet. } \\
\text { - Agreements with univer- } \\
\text { sities } \\
\text { - Agreements existed } \\
\text { before the implementation } \\
\text { of Ol }\end{array}$ & $\begin{array}{l}\text {-Practice license out, but not integrat- } \\
\text { ed to Ol } \\
\text { - Agreements with universities by } \\
\text { means of contracting PhDs or funding } \\
\text { research that last for } 2 \text { years in } \\
\text { general, and contemplate contracting } \\
\text { post-graduates for the internal labora- } \\
\text { tories. } \\
\text { - Existing agreements with universities } \\
\text { are seen as very complex in terms of } \\
\text { contracting. }\end{array}$ & $\begin{array}{l}\text {-Don't practice license out } \\
\text { - Currently hold partnerships } \\
\text { with UFRJ, UFF, University of } \\
\text { Aquilla, University of Drexel, } \\
\text { University of Pittsburgh, Sie- } \\
\text { mens Corporate Research and } \\
\text { Siemens Norway. } \\
\text {-Agreements existed before } \\
\text { the implementation of OI and } \\
\text { last from } 4 \text { months to one year. }\end{array}$ \\
\hline
\end{tabular}

Table 7- Metrics and results

ISSN: 07 I8-2724. (http://www.jotmi.org) 
capability to manage intellectual property, which added by the legal requirements made by companies, become impeditive for obtaining joint patents.

It has not been identified, in the three firms, the existence of strategic adherence to achieve $\mathrm{Ol}$, as suggested by West and Gallagher (2006), apart from Natura's coordination and alignment with universities and S\&TI.

The implementation of $\mathrm{Ol}$ foresees spin-outs, sale and donation of firm's complements, which have not observed in the cases analysed. The creation of Ybios, a spin-off born at Natura in partnership with Centroflora, occurred before the implementation of the $\mathrm{OI}$ in the company. IBM patent donation has been classified as a marketing activity for the company, not Ol. The results generated by $\mathrm{Ol}$ could not be measured and identified so far: both revenue and related costs, as much as those related to the development of $\mathrm{Ol}$ mechanisms.

Siemens and Natura, metrics - not defined formally - prioritize the implementation of process evaluation, resources and competencies, which does not guarantee technological innovation capability, but value learning process. Natura affirmed that the firm evaluates its formal links with universities and S\&TI by the amount of research and joint research contracts. On the other hand, IBM focuses on financial metrics and questions the use of patent numbers as parameter. Despite the formal structuring of $\mathrm{Ol}$ at Natura and Siemens, the results of this strategy are not expected in the short term. There is no additional revenue generation so far with the practice of $\mathrm{Ol}$ in these organizations.

\section{Conclusions and remarks}

The objective of this study was to analyze the implementation of OI in large companies located in Brazil: Natura, IBM and Siemens. With this approach, it has been identified how companies employed its corporative strategies; the strategy and the process of implementation, involving definition of the team for the implementation as well as its characteristics; the requirements for this process, such as culture, abilities and motivation; the barriers and enablers; and the results encountered. The answers had been analyzed according to the DSC method, grouping answers according to the target categories proposed in this study.

The conclusions of this study showed that there is no uniformity in terms of how the strategic decisions are made. It has been observed that the implementation of OI was consolidated only in one the analyzed companies, Natura. It was seen a beginning of related activities at Siemens/Chemtech and an opposition to these principles at IBM. Those facts increase the difficulty for more consistent analysis.
The strategic motivation for Ol does not appear in the search of new sources of income by licensing or attracting Venture Capital. Instead, it values resources available from the government, as well as reduction of cost and time in the development of new products.

Part of the opening process was implemented, but there is no perspective of implementing the full process. Inside-out it does not seem to be an action that has been integrated to the process of opening in these companies. Spontaneously, interviewees at Natura and Siemens had not mentioned that this action was important for the strategy of their companies. In this sense, it should be questioned if companies are actually searching for new sources of income, or if they are primarily focusing on cost and speed in the access of knowledge and the internalization of ideas and technology, because focusing in inside-out actions seems not to be a priority.

With regard to the strategy and process of implementation and formation of teams, Ol structuring seems to be necessary, and its association with the existing R\&D is important, as much as the centralization of activities in large companies. Although two of the companies have had support from the top management in the implementation of Ol, internal culture of individuals is still is a strong barrier. The three companies are structured internally to assimilate knowledge and to develop technological capacity by means of partnerships with universities. However, flexibility in the structure is more valued than the organizational consolidation for the incorporation of Ol.

The support given by the top management and the internal culture can be presented as requirements, but also as barriers or enablers, depending on the approach employed. IBM, thanks to the extreme control on its resources - intellectual property and core competencies - opts for a more closed model of for innovation and promotes a controlled opening, by purchasing of start-up companies and by donating or commercializing its patents, having as pay back, a technological trajectory.

Natura demands for shorter cycles of innovation and the launching of new products in the market and, for this reason, it is not fulfilled by adopting the closed innovation model. Chemtech, as a services company, requires constant updates not to become vulnerable in face of the competition. This reality motivates the studied firms to develop the requirements for Ol with higher intensity to fulfill their needs.

The promotion of relationships for the use of technological capacity is evident as well as the occurrence of formal and informal links between firms and universities/research institutes. It has to be said that these companies already had cooperation as part of their history, long before the imple- 
mentation of the Ol concept. It has been observed that external factors were mentioned in the answers as the ones that most create barriers to Ol: this are attributed to the characteristics of university and S\&TIs such as low speed during the processes, the lack of legal ability to manage intellectual capital and, mainly, the culture.

The enabling factors encountered confirm the theoretical review but, in spite of that, it can be said that the main barrier was not the same one: the weight attributed to the lack of culture and structure for $\mathrm{OI}$ in the universities and S\&TIs, as well as the cultural difference of these in comparison to the firms, presented different relevance of the presented one and inverted the order of importance of the barriers that were found.

The metrics related to results, those that focus on the process of innovation and the innovative capacity of the company can be applied to some extent in OI.The metric focusing on learning are the ones that are most easily matched with the practice of Ol. Moreover, greater weight is attributed to results relating to outside-in.

Economic and time related results cannot be explored in the current stage of implementation. It has been considered that there is a long journey to go before the consolidation of the Ol implementation in the studied companies. Taking into account the risk, time, effort and investment, in several cases, the evaluation of cost-benefit becomes a discouraging factor for the practice of Ol. There are still opportunities for capturing value based on assets by incorporating new sources of revenue with spin-offs, licensing, selling technology, which demonstrates that the process is still new, and also that there is a large field for research in relation to the metrics applied to $\mathrm{OI}$ and its results.

The limitations of this study are those common to qualitative approaches, as well as the number of cases presented that does not allow for generalizations, the distinct characteristics of each firm and the number of respondents per firm that, if amplified, could generate more in-depth analysis of the topic.

Future suggestions for related studies include an approach that takes maturity of $\mathrm{Ol}$ in the firms and specific metrics for its implementation.

\section{References}

CHRISTENSEN, C. A inovação e a empresa madura. HSM Management. São Paulo, 23/ano4, nov/dez. 2000.

CHESBROUGH, H.W. Why companies should have Open Business Models. MIT Sloan, winter 2007.

. The Era of Open Innovation. MIT Sloan Management Review, Spring 2003.

CHESBROUGH, H Crowther, Ak. Beyond high tech: early adopters of open innovation. R\&D Management, Vol 36, Nro. 3., pp. 229-236, Junho/2006.

DRUCKER, P. Inovação e o espírito empreendedor:prática e princípios. São Paulo: Pioneira Thomson, 2003.

EISENHARDT, K. M.; Graebner, M. E. Theory Building From Cases: Opportunities and Challenges. Academy of Management Journal, 2007, Vol. 50, No. I, 25-32.

ENKEL, E.; Gassmann, O.; Chesbrough, H. Open R\&D and open innovation. R\&D Management, 39, 4, 2009.

FIGUEIREDO, P. Gestão da Inovação: conceitos, métricas e experiências de empresas no Brasil. I ${ }^{a}$. Ed. Rio de Janeiro: LTC, 2009

KNUDSEN, L.G.Opening the Black Box of open innovation: organizational practice, employee competences, ans knowledge processes. Druid-Dime Academy Winter 2007. Phd Conference on Geografy, Innovation ans Industrial Dynamics. Aalborg, Denmark, January, 25-27, 2007.

LEFÈVRE, F.; Lefèvre,A. M. C. O discurso do sujeito coletivo: um novo enfoque em pesquisa qualitativa (desdobramentos). Caxias do Sul: UDUCS, 2005.

MORTARA, L. et. al. How to implement open innovation: lessos from studying large multinational companies. University of Cambridge, IFM: 2009.

MOORE, G. . Solução para o insolúvel. HSM Management. São Paulo, 67, mar/abr. 2008.

RICHARDSON, R. Pesquisa social: métodos e técnicas. $3^{\mathrm{a}}$. ed. São Paulo:Atlas, 1999.

ROHRBECK, R.; Hölzle, K.; Gemünden, H. G. Opening up for competitive advantage - How Deutsche Telekom creates an open innovation ecosystem. R\&D Management 39, 4, 2009.

ISSN: 07 I8-2724. (http://www.jotmi.org)

Journal of Technology Management \& Innovation (c) Universidad Alberto Hurtado, Facultad de Economía y Negocios. 
RUIZ,J.A. Metodologia científica. $3^{\text {a }}$. ed. São Paulo:Atlas, 1992. SAMPIERI, R. H.; Collado, C. H.; Lucio, P. B. Metodologia de pesquisa. $3^{a}$ edição. São Paulo: McGraw-Hill, 2006.

TAKAHASHI, S.;Takahashi,V.p.Gestão de inovação de produtos: estratégia, processo, organização e conhecimento. Rio de Janeiro: Elsevier, 2007.

TIDD, J. et al. Gestão da Inovação. $3^{a}$. Ed. Porto Alegre: Bookman, 2008.

VISKARI, S.; Salmi, P.; Torkkeli, M . Implementation of open innovation paradigm - cases: Cisco Systems, DuPont, IBM, Intel, Lucent, P\&G, Philips and Sun Microsystems. Research Report. Department of Industrial Management. Lappeenranta University of Technology. Finland, 2007.

WEST, J.; Gallagher, S. Challenges of open innovation: the paradox of firm investment in open-source software. R\&D Management 36, 3, 2006. 